\title{
Article \\ Synthesis and Characterization of MgO Thin Films Obtained by Spray Technique for Optoelectronic Applications
}

\author{
Maher Tlili ${ }^{1}$, Chayma Nefzi ${ }^{1}$, Badriyah Alhalaili ${ }^{2}$, Chaker Bouzidi $^{3}$, Lassaad Ajili ${ }^{3}$, Neila Jebbari ${ }^{1,4}$, \\ Ruxandra Vidu $5,6, * \mathbb{B}$ and Najoua Turki Kamoun ${ }^{1}$
}

1 Laboratoire de Physique de la Matière Condensée, Département de Physique, Faculté des Sciences de Tunis, Université Tunis El Manar, Campus Universitaire, Tunis 2092, Tunisia; maherbargaoui@gmail.com (M.T.); chaimanefzi2021@gmail.com (C.N.); neilajebbari@gmail.com (N.J.); n.najouakamoun@gmail.com (N.T.K.)

2 Nanotechnology and Advanced Materials Program, Kuwait Institute for Scientific Research, P.O. Box 24885, Safat 13109, Kuwait; bhalailil@kisr.edu.kw

3 Centre National des Recherches en Sciences des Matériaux (CNRSM), Laboratoire de Physico-Chimie des Matériaux Minéraux et Leurs Applications, Borj Cedria Technopark, BP 73, Soliman 8027, Tunisia; chaker.bouzidi1978@gmail.com (C.B.); lassaad.laajili@gmail.com (L.A.)

4 Institut Préparatoire aux Etudes d'Ingénieurs d'El Manar, B.P. 244 El Manar II, Tunis 2092, Tunisia

5 Faculty of Materials Science and Engineering, University POLITEHNICA of Bucharest, 060042 Bucharest, Romania

6 Department of Electrical and Computer Engineering, University of California Davis, Davis, CA 95616, USA

* Correspondence: rvidu@ucdavis.edu; Tel.: +1-(916)792-6272

check for updates

Citation: Tlili, M.; Nefzi, C.; Alhalaili, B.; Bouzidi, C.; Ajili, L.; Jebbari, N.; Vidu, R.; Turki Kamoun, N. Synthesis and Characterization of MgO Thin Films Obtained by Spray Technique for Optoelectronic Applications. Nanomaterials 2021, 11, 3076. https://doi.org/10.3390/ nano11113076

Academic Editor: Baoquan Sun

Received: 30 August 2021

Accepted: 7 November 2021

Published: 15 November 2021

Publisher's Note: MDPI stays neutral with regard to jurisdictional claims in published maps and institutional affiliations.

Copyright: (C) 2021 by the authors. Licensee MDPI, Basel, Switzerland. This article is an open access article distributed under the terms and conditions of the Creative Commons Attribution (CC BY) license (https:/ / creativecommons.org/licenses/by/ $4.0 /)$.
Abstract: Magnesium oxide $(\mathrm{MgO})$ thin films with different magnesium concentrations $\left(\left[\mathrm{Mg}^{2+}\right]=0.05\right.$, $0.1,0.15$ and $0.2 \mathrm{~mol} \cdot \mathrm{L}^{-1}$ ) in a spray solution have been successfully grown using a spray pyrolysis technique. X-ray diffraction (XRD), Maud software, FTIR spectroscopy, a confocal microscope, Wien $2 \mathrm{k}$ software, spectrophotometry and a Photoluminescence spectrometer were used to investigate the structural, morphological and optical properties. XRD analysis revealed a better crystalline quality of the $\mathrm{MgO}$ thin layer synthesized with $\left[\mathrm{Mg}^{2+}\right]=0.15 \mathrm{~mol} \cdot \mathrm{L}^{-1}$, which crystallized into a face-centered cubic structure along the preferred orientation (200) lattice plan. The enhancement of the crystalline quality for the $\mathrm{MgO}$ thin film $\left(\left[\mathrm{Mg}^{2+}\right]=0.15 \mathrm{~mol} \cdot \mathrm{L}^{-1}\right)$ was obtained, which was accompanied by an increment of $94.3 \mathrm{~nm}$ of the crystallite size. No secondary phase was detected and the purity phase of the $\mathrm{MgO}$ thin film was confirmed using Maud software. From the transmission spectra results, high transparent and antireflective properties of the $\mathrm{MgO}$ thin film were observed, with an average transmission value of about $91.48 \%$ in the visible range, which can be used as an optical window or buffer layer in solar cell applications. The films also have a high reflectance value in the IR range, which indicates that the highly reflective surface will prevent an increase in surface temperature under solar irradiation, which could be beneficial in solar cell applications. A direct band gap type was estimated using the Tauc relation which is close to the experimental value of $4.0 \mathrm{eV}$ for optimal growth. The $\mathrm{MgO}$ material was tested for the degradation of methylene blue (MB), which reached a high photodegradation rate of about $83 \%$ after $180 \mathrm{~min}$ under sunlight illumination. These experimental trends open a new door for promising the removal of water contaminants for photocatalysis application.

Keywords: magnesium oxide (MgO) thin film; physical properties; antireflective; photocatalysis application

\section{Introduction}

Magnesium oxide $(\mathrm{MgO})$ belongs to the transparent oxide family and crystallizes into a face-centered cubic structure, having $\mathrm{a}=\mathrm{b}=\mathrm{c}=4.217 \dot{\mathrm{A}}[1,2]$. It is characterized by high transmission values in the visible range near to $90 \%$ [3] and a wide direct band gap of $7.8 \mathrm{eV}$ for pure $\mathrm{MgO}$ [4]. Heo et al. [5] measured a gap energy lower than $7.8 \mathrm{eV}$ and attributed the low band-gap energies to the existence of defects in type $F_{S}$ and $F_{B}$. 
A MgO material has the following main advantages: non-toxicity [6], an abundance of its constituents as well as chemical and physical stability [7]. These properties recommend $\mathrm{MgO}$ for a wide range of applications in which its antibacterial [8], antimicrobial [9] and photo-catalytic properties [3,10] could be used. Moreover, $\mathrm{MgO}$ can be used for photovoltaic devices [11,12] and gas sensor applications [13].

Many experimental techniques have been developed to obtain $\mathrm{MgO}$ materials, such as: thermolysis of an ultrathin $\mathrm{Mg}(\mathrm{OH})_{2}$ precursor under a dynamic vacuum to obtain ultrathin single-crystalline $\mathrm{MgO}$ nanosheets with a preferential orientation stacked by (111) planes [6], sol-gel [14-16], chemical vapor deposition (CVD) [17], pulsed laser deposition [18], reactive sputtering [19], laser ablation [20], metal organic molecular beam epitaxy [21] and a chemical spray pyrolysis technique [3,22]. Currently, heavy environmental pollution has motivated researchers to seek new treatments, such as the extractivepyrolytic method [23], to remove pollutants and protect the environment. For these reasons, semiconductor materials are involved in the photocatalysis process for the degradation of organic pollutants, which are hazardous to human health and harmful for the environment. In this work, many experimental techniques and tools are used to investigate the magnesium oxide thin film, such as X-ray diffraction (XRD), FTIR spectroscopy, Maud software, confocal microscopy, spectrophotometry and photoluminescence spectrometry. The main goal of this study is to investigate the physical behaviors of sprayed magnesium oxide thin films with different magnesium concentrations in the sprayed solution $\left(\left[\mathrm{Mg}^{2+}\right]=0.05,0.1\right.$, 0.15 and $0.2 \mathrm{~mol} \cdot \mathrm{L}^{-1}$ ) and look for possible optoelectronic applications.

\section{Materials and Methods}

$\mathrm{MgO}$ thin layers were synthesized on glass substrates using the liquid-phase spray pyrolysis technique. Before the deposition process, all glass substrates were cleaned in an ultrasonic bath containing double-distilled water. Magnesium II chloride hexahydrate $\left(\mathrm{MgCl}_{2}, 6 \mathrm{H}_{2} \mathrm{O}, 99 \%\right)$ was purchased from AppliChem (Council Bluffs, IA, USA). $\mathrm{MgCl}_{2}$ was dissolved in $100 \mathrm{~mL}$ of bi-distilled water. This solution, which contained the precursor, was sprayed onto preheated substrates as fine droplets by means of compressed air as a carrier gas. During the deposition process, the substrate temperature was maintained at $450{ }^{\circ} \mathrm{C}$ and the solution flow rate was kept at $10 \mathrm{~mL} / \mathrm{min}$. In this work, we varied magnesium concentrations $\left(\left[\mathrm{Mg}^{2+}\right]=0.05,0.1,0.15,0.2 \mathrm{~mol} \cdot \mathrm{L}^{-1}\right)$ to study the physical properties of the $\mathrm{MgO}$ material.

The crystalline structure of the thin films was studied by XRD using an X-ray diffractometer with a $1.5418 \AA \mathrm{Cu}-\mathrm{K} \alpha$ ray (automated Bruker D8 apparatus, Karlsruhe, Germany). The experimental XRD spectra were compared with the Maud software. FTIR spectroscopy (type VERTEX80 spectrometer for $400-4000 \mathrm{~cm}^{-1}$, Billerica, MA, USA) was performed to identify the existence of different molecules and ions on the sample surface, and the existence of $\mathrm{MgO}$ in particular. Morphological analysis was performed using a confocal microscope called "SENSOFAR". Optical measurements were performed using a Perkin Elmer Lambda 950 spectrometer (Bridgeport, CT, USA). The type and value of the band gap were calculated using the Tauc relation. The photocatalysis process of the $\mathrm{MgO}$ thin layer was tested by degrading aqueous methylene blue (MB, 95\%, from Sigma Aldrich, Bengaluru, Karnataka, India) under sunlight irradiation at room temperature and ambient air. Thus, to prepare the aqueous $\mathrm{MB}$ solution, $5 \mathrm{mg}$ of $\mathrm{MB}$ powder was dissolved in double-distilled water (from Bi-distiller water GFL, Burgwedel, Germany) to reach $10^{-5} \mathrm{M}$ of dye solution. Next, each sample was immersed in $20 \mathrm{~mL}$ of aqueous MB solutions. Then, all solutions were placed in the dark for $30 \mathrm{~min}$ before exposing them to light in order to achieve the adsorption-desorption equilibrium state. The degradation of MB dye was measured at different periods of time (from $30 \mathrm{~min}$ to $3 \mathrm{~h}$, in steps of $30 \mathrm{~min}$ ), using a Perkin Elmer Lambda 950 spectrophotometer. 


\section{Results and Discussion}

\subsection{XRD Analysis}

In order to study the effect of magnesium concentrations on the structural property of $\mathrm{MgO}$ thin films, different amounts of $\mathrm{Mg}$ were used $\left(\left[\mathrm{Mg}^{2+}\right]=0.05,0.1,0.15\right.$ and $\left.0.2 \mathrm{~mol} \cdot \mathrm{L}^{-1}\right)$. The diffractograms obtained by scanning the $2 \theta$ range between $20^{\circ}$ and $80^{\circ}$ are presented in Figure 1. The XRD patterns of the synthesized $\mathrm{MgO}$ obtained for $\left[\mathrm{Mg}^{2+}\right]=0.05-0.1 \mathrm{~mol} \cdot \mathrm{L}^{-1}$ show low-intensity peaks. The XRD scans of the $\mathrm{MgO}$ thin films present characteristic peaks that correspond to (111), (200) and (222) plans, which are attributed to the face-centered cubic structure (JCBD card No\# 650476) with space group $\mathrm{fm} \overline{3} \mathrm{~m}$. The onset of $\mathrm{MgO}$ polycrystalline material was observed at $\left[\mathrm{Mg}^{2+}\right]=0.15-0.2 \mathrm{~mol} \cdot \mathrm{L}^{-1}$. It is observed that the crystallinity increases with the increase in the intensity of the (200) preferred orientation for an $\mathrm{Mg}$ concentration of $0.15 \mathrm{~mol} \cdot \mathrm{L}^{-1}$. However, an increase in $\mathrm{Mg}$ concentration to $0.2 \mathrm{~mol} \cdot \mathrm{L}^{-1}$ results in a slight deterioration of crystallinity. The crystallite size D (nm) was calculated using the Debye-Scherrer equation [3,24]:

$$
D=\frac{k \lambda}{\beta \cos (\theta)}
$$

where the constant $k$ equals 0.9 , the wavelength of the incident $\mathrm{X}$-ray is $\lambda=1.54 \mathrm{~nm}, \beta$ is the full width at half-maximum of the diffraction peak and $2 \theta$ is the position of the preferred orientation (200).

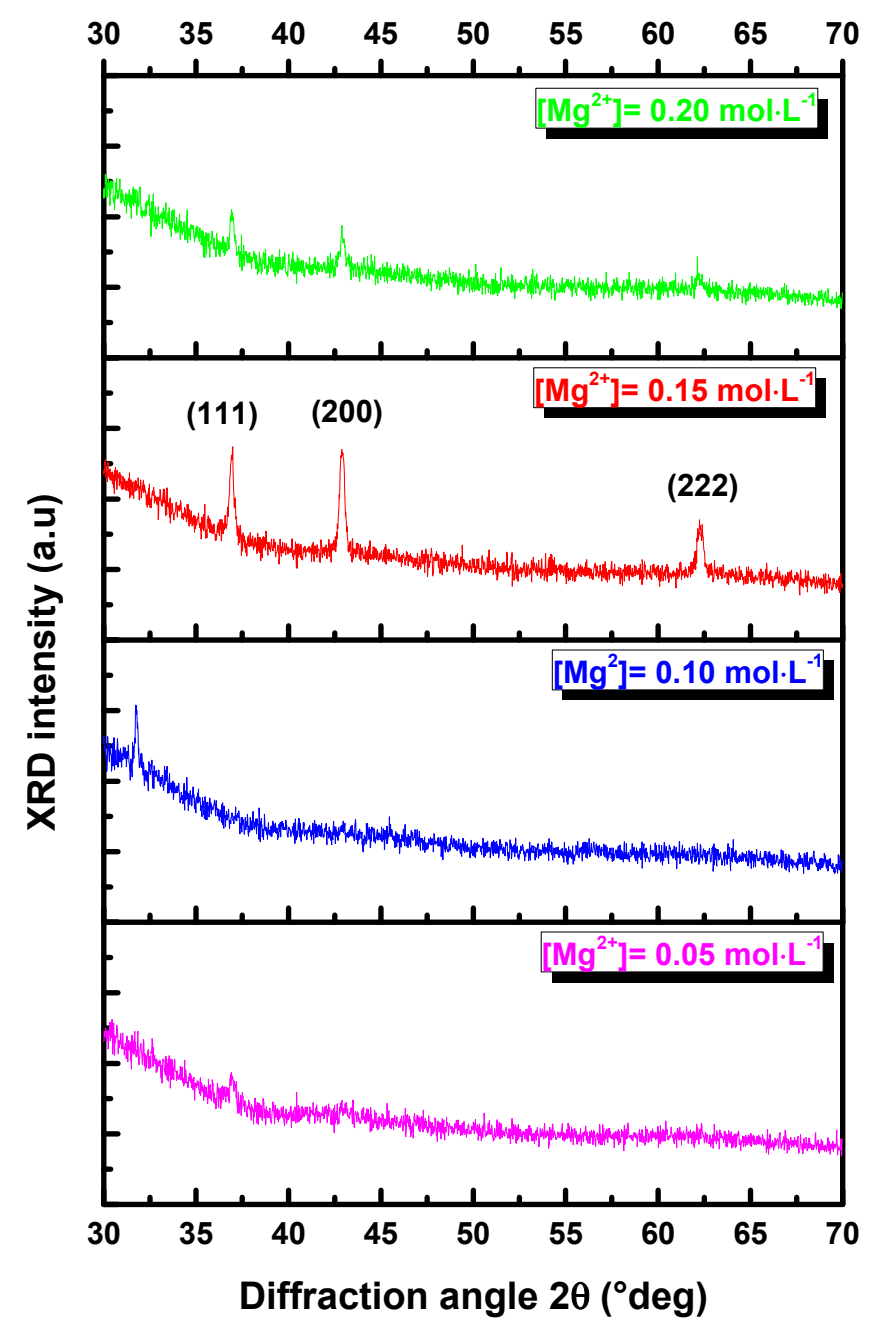

Figure 1. X-ray spectra of $\mathrm{MgO}$ thin films deposited on glass substrates for different concentrations $\left(\left[\mathrm{Mg}^{2+}\right]=0.05 ; 0.10 ; 0.15\right.$ and $\left.0.20 \mathrm{~mol} \cdot \mathrm{L}^{-1}\right)$. 
Table 1 summarizes the calculated crystallite size (D), dislocation density $\left(\delta_{\text {dis }}=\frac{1}{D^{2}}\right)$ per unit area and the strain $\left(\varepsilon=\frac{\beta \cos \theta}{4}\right)$ of $\mathrm{MgO}$ thin films synthesized with different $\mathrm{Mg}$ concentrations. The results of these calculations show that $\mathrm{D}$ increases with increasing magnesium concentrations, reaching the highest value of about $9 \mathrm{~nm}$ at $\left[\mathrm{Mg}^{2+}\right]=0.15 \mathrm{~mol} \cdot \mathrm{L}^{-1}$. The maximum size of $\mathrm{MgO}$ crystallite $(\mathrm{D}=9 \mathrm{~nm})$ obtained by the spray technique is less than $\mathrm{D}=50 \mathrm{~nm}$, obtained by Demirci et al. [10], who grew $\mathrm{MgO}$ by flame spray pyrolysis, but larger than $\mathrm{D}=7.8 \mathrm{~nm}$, obtained by Poonguzhali et al. [2] for $\mathrm{MgO}$ nanorods. It is worth mentioning that this trend is correlated with the improvement in crystalline quality, as seen in Figure 1 . Moreover, Table 1 shows that the dislocation density $\delta_{\text {dis }}$ was reduced from $35.45 \times 10^{15} \mathrm{~cm}^{-2}$ for $\left[\mathrm{Mg}^{2+}\right]=0.1 \mathrm{~mol} \cdot \mathrm{L}^{-1}$ to $12.1 \times 10^{15} \mathrm{~cm}^{-2}$ for $\left[\mathrm{Mg}^{2+}\right]=0.15 \mathrm{~mol} \cdot \mathrm{L}^{-1}$. A similar trend was observed for the strain, which varied in the range of $0.065 \times 10^{-3}-0.043 \times 10^{-3} \%$.

Table 1. Structural parameters of $\mathrm{MgO}$ thin layers grown by spray for different magnesium concentrations: $\left[\mathrm{Mg}^{2+}\right]=0.05 ; 0.10 ; 0.15 ; 0.20 \mathrm{~mol} \cdot \mathrm{L}^{-1}$.

\begin{tabular}{|c|c|c|c|c|}
\hline $\begin{array}{c}\left.\mathrm{Mg}^{2+}\right] \\
\left(\mathrm{mol} \cdot \mathrm{L}^{-1}\right)\end{array}$ & $2 \theta\left({ }^{\circ}\right)$ & $\begin{array}{l}\text { Crystallite Size } \\
\text { D (nm) }\end{array}$ & $\begin{array}{c}\text { Dislocation Density } \\
\delta_{\text {dis }}\left(1^{15} \mathrm{~cm}^{-2}\right)\end{array}$ & $\begin{array}{c}\text { Micro Strain } \varepsilon \\
10^{-3}(\%)\end{array}$ \\
\hline 0.05 & - & - & - & - \\
\hline 0.10 & 42.38 & 5.31 & 35.5 & 0.065 \\
\hline 0.15 & 42.67 & 9.10 & 12.1 & 0.038 \\
\hline 0.20 & 42.50 & 8.00 & 15.6 & 0.043 \\
\hline
\end{tabular}

\subsection{Rietveld Analysis}

In order to refine the experimental XRD spectra and confirm the face-centered cubic structure of the $\mathrm{MgO}$ material, we used the Maud software (Materials Analysis Using Diffraction) based on the Rietveld analysis [3]. Additionally, we could estimate the lattice parameter and crystallite size and we could extract the secondary phases, which may exist along with the $\mathrm{MgO}$ phase. Figure 2 illustrates the Rietveld refinement of the XRD spectrum for the $\mathrm{MgO}$ thin layer prepared using a spray solution containing $\left[\mathrm{Mg}^{2+}\right]=0.15 \mathrm{~mol} \cdot \mathrm{L}^{-1}$. The results show that no secondary phase exists along with the $\mathrm{MgO}$ phase, which proves the purity of the $\mathrm{MgO}$ material. We obtained a high goodness-of-fit (GOF) equal to 1.05. The crystallite size value was about $11.02 \mathrm{~nm}$, which is very close to the experimental value obtained in Table 1. After applying the fitting analysis, we obtained a lattice parameter equal to $\mathrm{a}=4.52 \dot{\mathrm{A}}$, which is in good agreement with the JCPDF card No. \#650476.

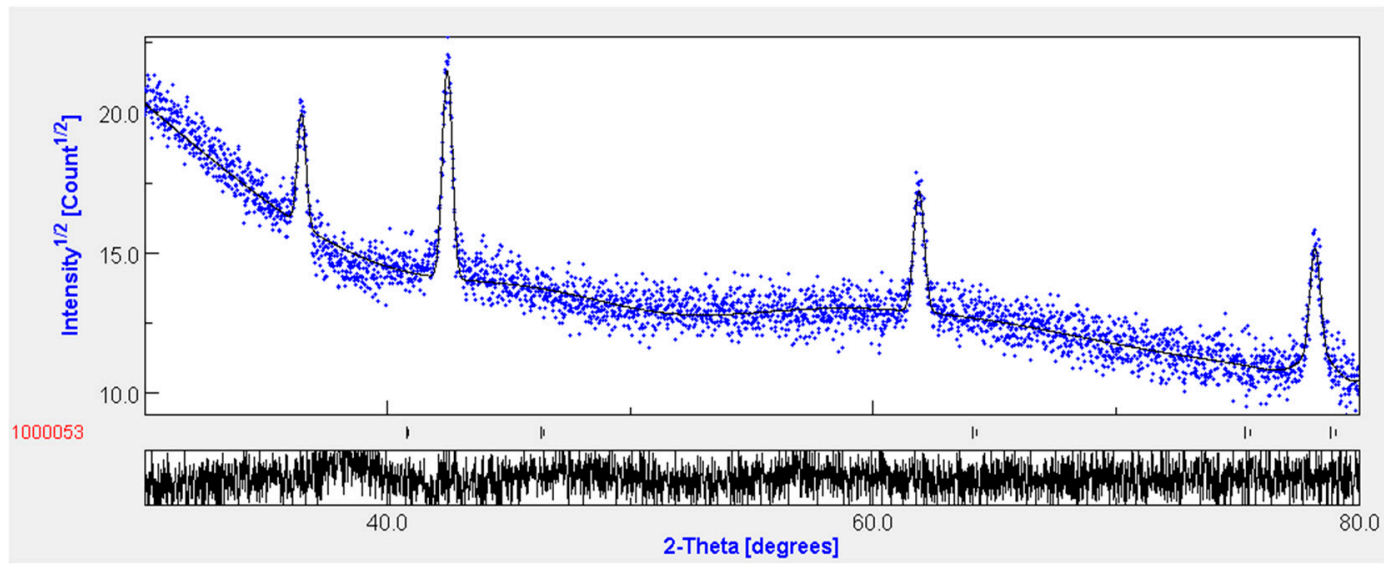

Figure 2. Rietveld refinement of optimum $\mathrm{MgO}$ film grows by spray pyrolysis with $\left[\mathrm{Mg}^{2+}\right]=0.15 \mathrm{~mol} \cdot \mathrm{L}^{-1}$. 


\subsection{FTIR Spectra}

The FTIR spectra of the $\mathrm{MgO}$ thin films deposited with $\left[\mathrm{Mg}^{2+}\right]=0.05 ; 0.10 ; 0.15$ and $0.20 \mathrm{~mol} \cdot \mathrm{L}^{-1}$ show two peaks located at $553 \mathrm{~cm}^{-1}$ and $1272 \mathrm{~cm}^{-1}$ (Figure 3). The peak at $553 \mathrm{~cm}^{-1}$ indicates the stretching vibration of $\mathrm{MgO}$ which was reported by Ashok et al. [24], who obtained $\mathrm{MgO}$ nanoparticles using a microwave irradiation technique and found a vibrational of $\mathrm{MgO}$ at $588 \mathrm{~cm}^{-1}$; they also mentioned that $\mathrm{MgO}$ has a stretching vibration in the range of $550-670 \mathrm{~cm}^{-1}$. Tlili et al. [3] prepared $\mathrm{MgO}$ thin films by a spray pyrolysis technique and they found a vibrational of $\mathrm{MgO}$ at $459 \mathrm{~cm}^{-1}$. Kandiban et al. [25] synthesized $\mathrm{MgO}$ nanoparticles using co-precipitation and a hydrothermal method and found a vibrational of $\mathrm{MgO}$ at $548 \mathrm{~cm}^{-1}$.

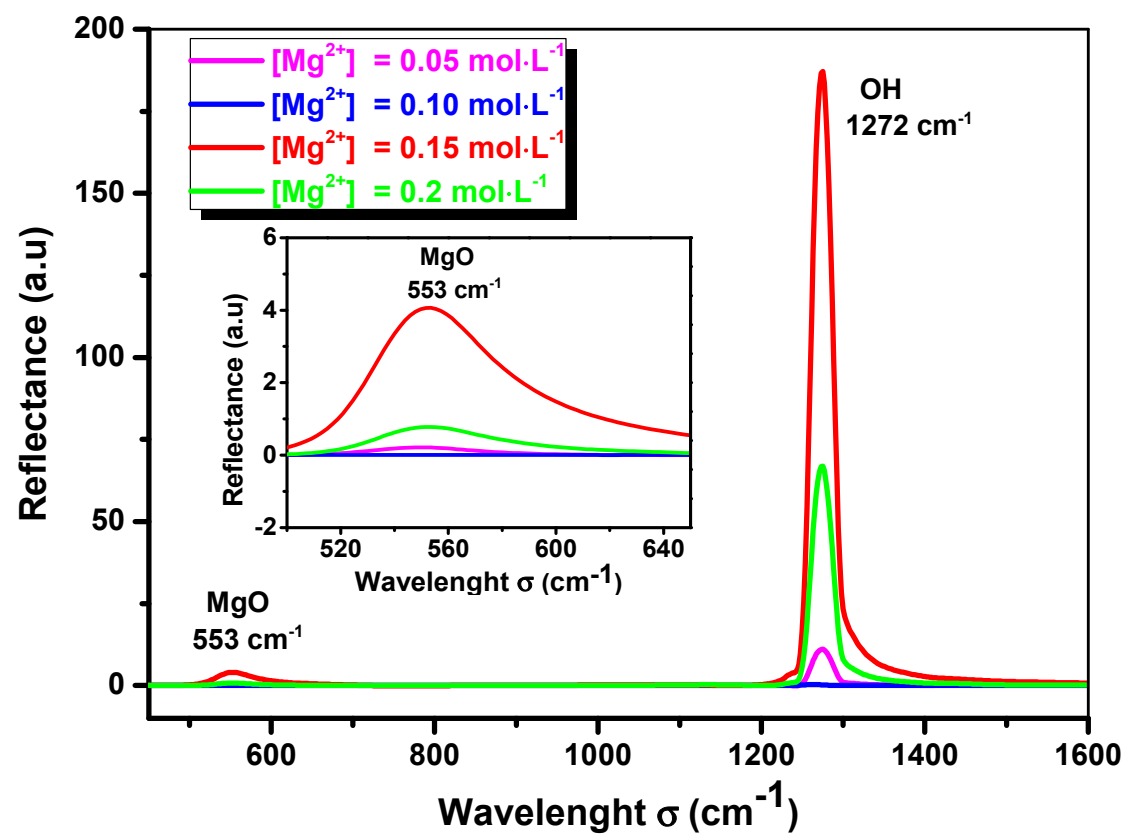

Figure 3. FTIR spectra of sprayed $\mathrm{MgO}$ thin films deposited with $\left[\mathrm{Mg}^{2+}\right]=0.05 ; 0.10 ; 0.15$ and $0.20 \mathrm{~mol} \cdot \mathrm{L}^{-1}$.

The peak located at $1272 \mathrm{~cm}^{-1}$ was assigned to the hydroxyl group $\mathrm{OH}$, which was reported by Moses et al. [22], who found the peak at $1228 \mathrm{~cm}^{-1}$, and by Devaraja et al. [26], who mentioned that the hydroxyl group of water has an absorption in the range of $1300-1800 \mathrm{~cm}^{-1}$. The spectrum presented in Figure 3 shows no other elements or impurities on the surface, such as carbon monoxide $\mathrm{CO}[24,25]$ or $\mathrm{H}^{-}, \mathrm{CO}_{3}{ }^{2-}$ (located at 1076 , $1435 \mathrm{~cm}^{-1}$ ) [27].

As the size of the particle decreases, the resolution of the vibrational bands is better resolved [28]. The peak intensity of $\mathrm{MgO}$ with $\left[\mathrm{Mg}^{2+}\right]=0.15 \mathrm{~mol} \cdot \mathrm{L}^{-1}$ is the largest of all peaks in the FTIR spectrum, which agrees well with the largest crystallite size obtained by $\mathrm{XRD}$, and is presented in Table 1.

\subsection{Surface Morphology}

To study the morphological aspects of the $\mathrm{MgO}$ thin layer, a 3D confocal microscope $(1764 \times 1321 \mu \mathrm{m})$ was used, as shown in Figure 4a. The micrograph clearly shows the uniform and dense aggregation of particles that have practically the same size. Moreover, the diagonal profile line of the scanned surface area gives an average thickness of about $0.4 \mu \mathrm{m}$, which is close to the value calculated from the double weight that equals $0.36 \mu \mathrm{m}$ for optimum growth. It is worth mentioning that the $\mathrm{MgO}$ thin film obtained using $\left[\mathrm{Mg}^{2+}\right]=0.15 \mathrm{~mol} \cdot \mathrm{L}^{-1}$ exhibits a rough surface morphology. This observation is very important, because a rough surface means a large contact surface, which is a beneficial feature in photocatalysis, humidity and sensor applications. The surface parameters of the 
$\mathrm{MgO}$ material obtained from the confocal microscope data show that the arithmetical mean height (Sa) value equals $0.15 \mu \mathrm{m}$ and the root mean square (Sq) equals $0.19 \mu \mathrm{m}$. It is clear that the $\mathrm{MgO}$ thin film is grown using $\left[\mathrm{Mg}^{2+}\right]=0.15 \mathrm{~mol} \cdot \mathrm{L}^{-1}$ with high roughness, which makes it a promising candidate for gas sensor applications as well as for photocatalysis water treatment [3].

a)
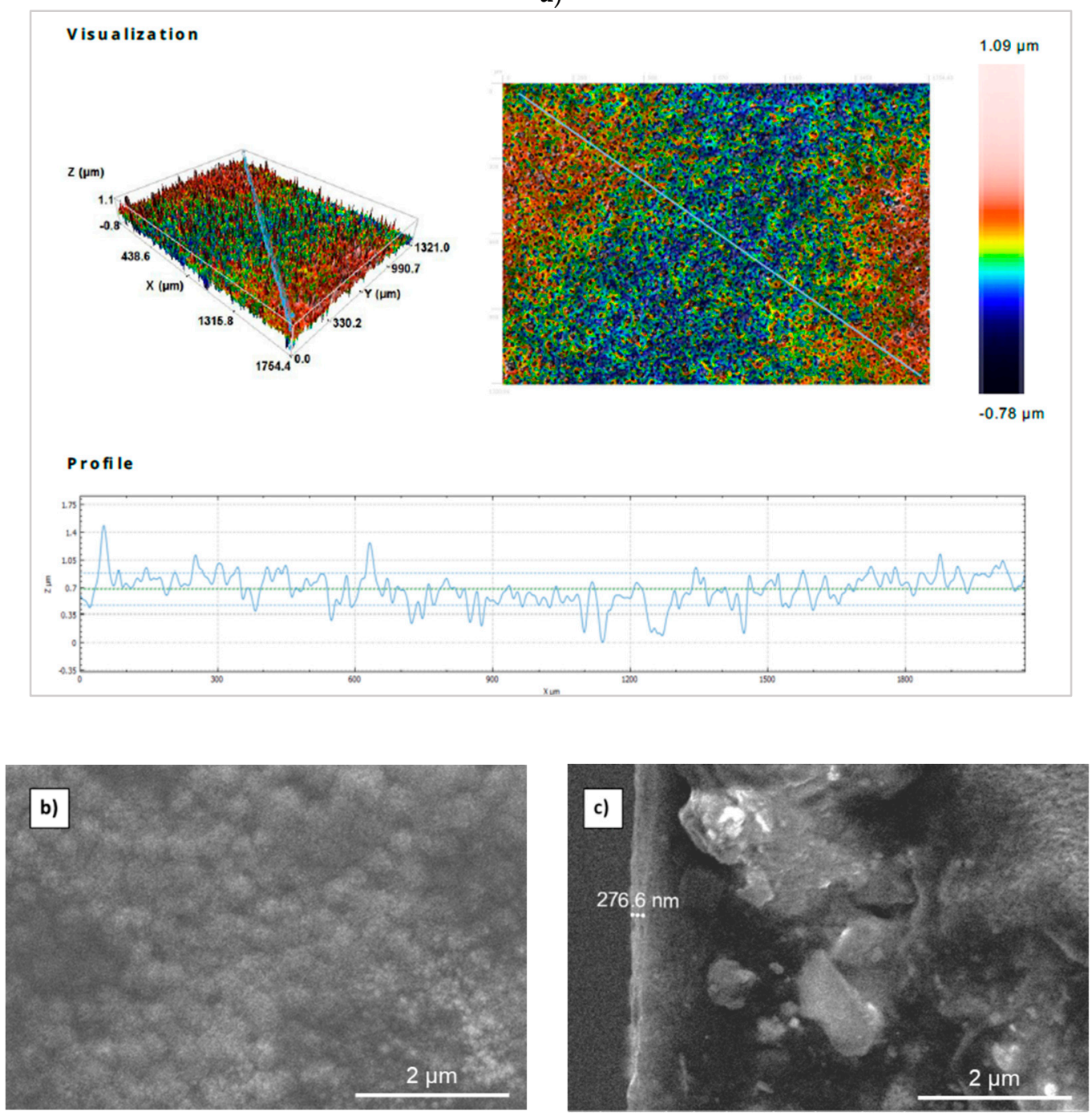

Figure 4. Confocal microscopy (a) and SEM images (top (b) and cross-section (c) views) of the MgO thin layer synthesized using $\left[\mathrm{Mg}^{2+}\right]=0.15 \mathrm{~mol} \cdot \mathrm{L}^{-1}$.

Figure $4 \mathrm{~b}, \mathrm{c}$ show the SEM images (top and cross-section views of the $\mathrm{MgO}$ thin film obtained using $\left[\mathrm{Mg}^{2+}\right]=0.15 \mathrm{~mol} \cdot \mathrm{L}^{-1}$. These images show a surface morphology characterized by spherical, droplet-like particles and a smooth, continuous film without any cracks. The SEM image of the cross-section view (Figure 4c) shows that the film has a thickness of $276.6 \mathrm{~nm}$. We also performed a double weighting method to assess the thickness of the layers. Using a precision balance of $0.0001 \mathrm{~g}$, the film thickness was estimated to be $290 \pm 25 \mathrm{~nm}$, which agrees well with the film thickness measured by SEM.

\subsection{Optical Analysis}

Using various magnesium concentrations in the spray solution, both morphological and structural behaviors will induce significant changes in the optical properties of $\mathrm{MgO}$. Figure 5 displays the transmission $\mathrm{T}(\%)$ and the reflectance R (\%) spectra of the $\mathrm{MgO}$ thin 
films in UV-Vis-IR regions. High transmission values in the visible range for all samples recommend the $\mathrm{MgO}$ thin film as an optical window or buffer layer in solar cell devices. Figure 5a shows that $\mathrm{T}(\%)$ values increase as the $\mathrm{Mg}$ concentration increases. Generally, the enhancement of $\mathrm{T}(\%)$ could originate from reduced scattering effects, the enhancement of crystallinity and structural homogeneity, as reported by $[29,30]$. On the other hand, a particular behavior was observed, i.e., T (\%) exceeded 100\% in the UV range around $\lambda=350 \mathrm{~nm}$. These results could be explained by the fact that the $\mathrm{MgO}$ thin film adsorbed $\mathrm{H}_{2} \mathrm{O}$ from the atmosphere. Thus, the water droplets which exist in the ambient air were well retained on the rough surface of the film, which in turn increased the transmission values, as mentioned earlier [3]. This observation indicates that the $\mathrm{MgO}$ thin film could be used as a humidity sensor.

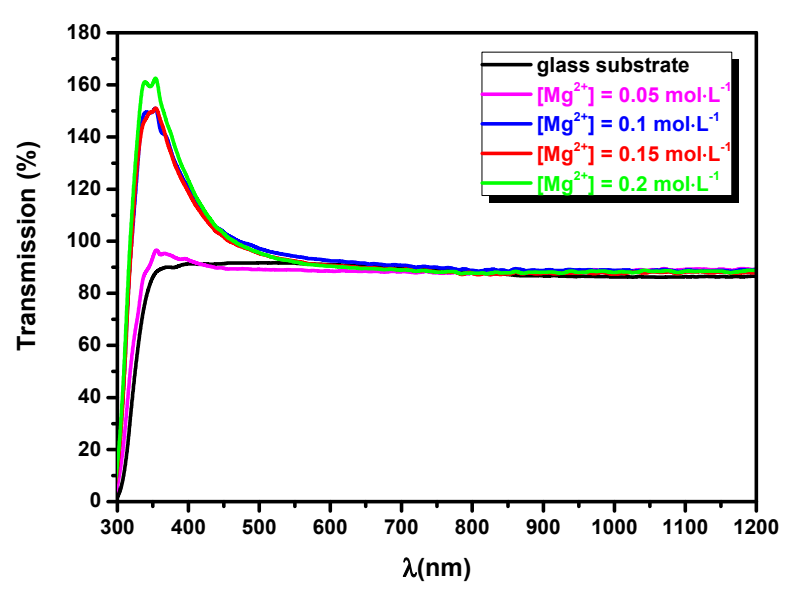

(a)

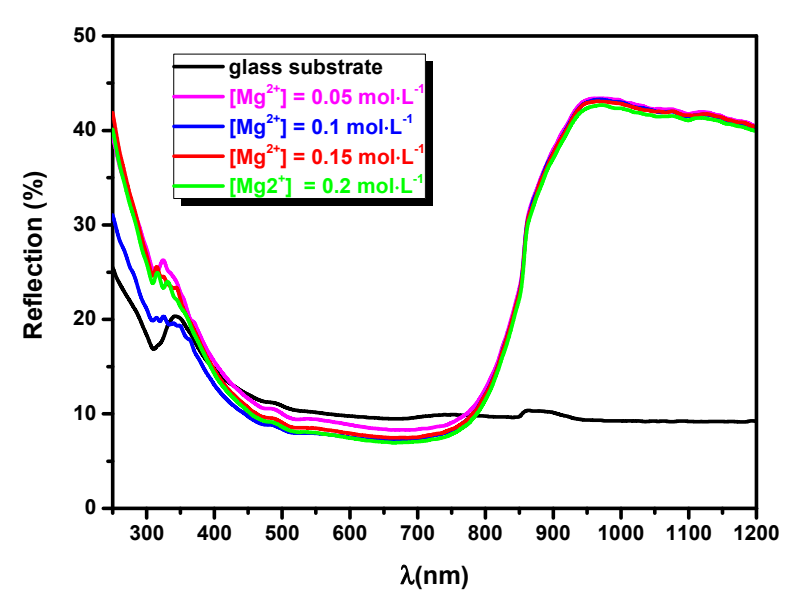

(b)

Figure 5. (a) Transmission and (b) reflectance spectra of sprayed $\mathrm{MgO}$ thin films grown for different concentrations $\left[\mathrm{Mg}^{2+}\right]=0.05 ; 0.10 ; 0.15$; and $0.20 \mathrm{~mol} \cdot \mathrm{L}^{-1}$.

The reflectance spectra presented in Figure $5 \mathrm{~b}$ show low intensity values close to $8 \%$ in the visible range for the $\mathrm{MgO}$ film obtained from a spraying solution containing $\left[\mathrm{Mg}^{2+}\right]=0.15 \mathrm{~mol} \cdot \mathrm{L}^{-1}$. In addition, high reflection values of $45 \%$ were obtained in the near-infrared region. These results indicate that a highly reflective surface will prevent an increase in surface temperature under solar irradiation, which could prove beneficial in solar cell applications. On the other hand, point defects may affect the optical absorption, as was observed in the $\mathrm{MgO}$ single crystal [2].

From the transmission $T(\lambda)$ and reflectance $R(\lambda)$ values, the absorption coefficient $(\alpha)$ can be analyzed using the following formula [30]:

$$
\alpha=\frac{1}{\mathrm{e}} \operatorname{Ln}\left(\frac{(1-\mathrm{R})^{2}}{\mathrm{~T}}\right)
$$

where $\mathrm{e}$ is the film thickness determined by the double weighting method.

The value and the type of the band gap energy were obtained from the Tauc relation,

$$
(\alpha \mathrm{h} v)=\mathrm{B}(\mathrm{h} v-\mathrm{Eg})^{\mathrm{n}}
$$

where $v=\mathrm{c} / \lambda, \mathrm{h}=6.62 \times 10^{-34} \mathrm{~J} . \mathrm{s}$ and $\mathrm{B}$ is a constant that depends on the transition probability. Experimental energy band gaps of $\mathrm{MgO}$ thin films were estimated by plotting $(\alpha \mathrm{h} v)^{2}$ versus $\mathrm{h} v(\mathrm{eV})$, as shown in Figure 6. The intersection of the quasi-linear part of curve with the $\mathrm{x}$-axis shows that the $\mathrm{MgO}$ thin film obtained using $\left[\mathrm{Mg}^{2+}\right]=0.15 \mathrm{~mol} \cdot \mathrm{L}^{-1}$ has a large energy band gap of $4 \mathrm{eV}$. Table 2 summarizes the energy band gap values. 
These values are lower than the band gap energy of pure and bulk $\mathrm{MgO}(7.8 \mathrm{eV})$. The large difference in band gap energy is attributed to the presence of default sites.

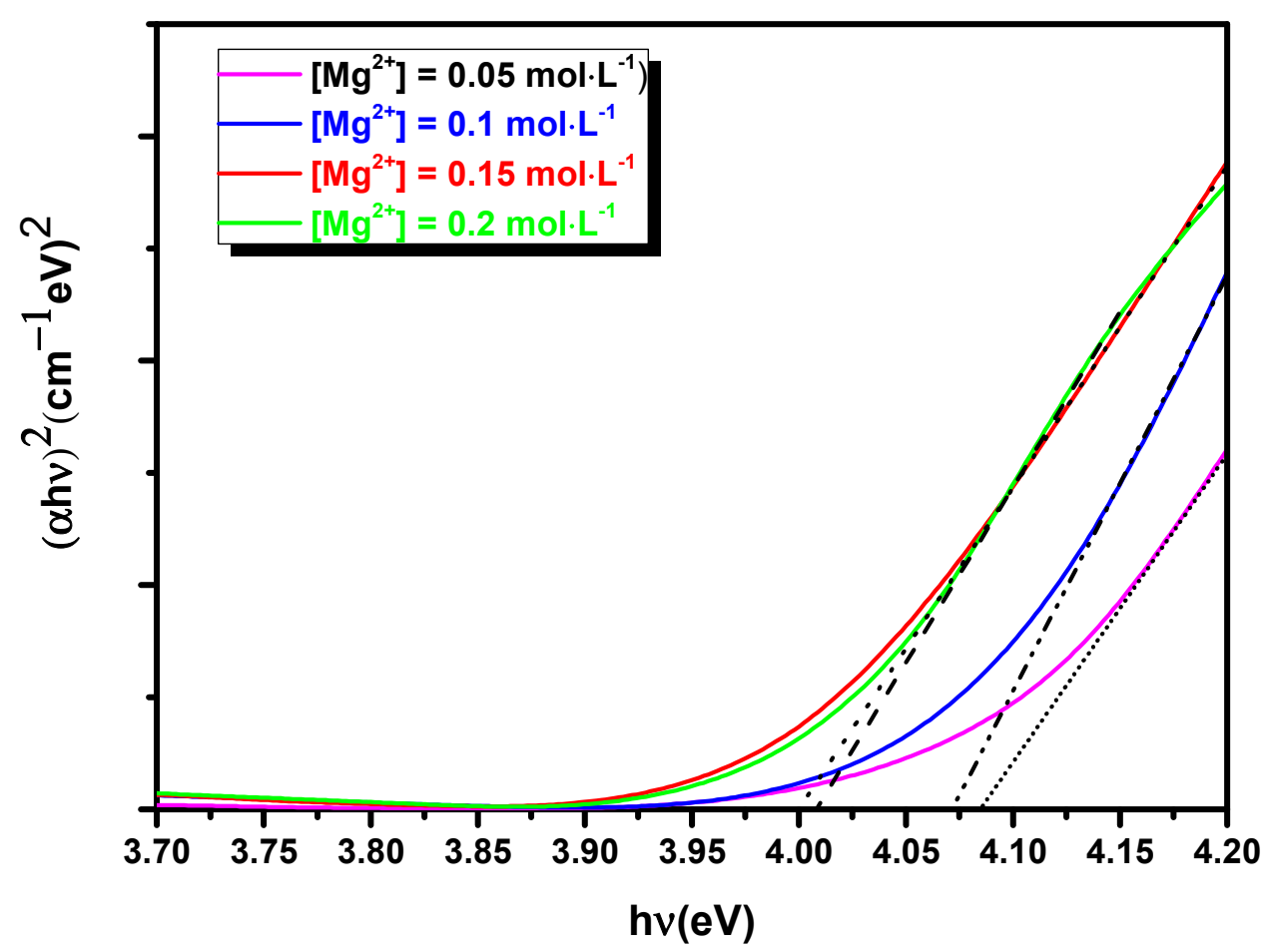

(a)

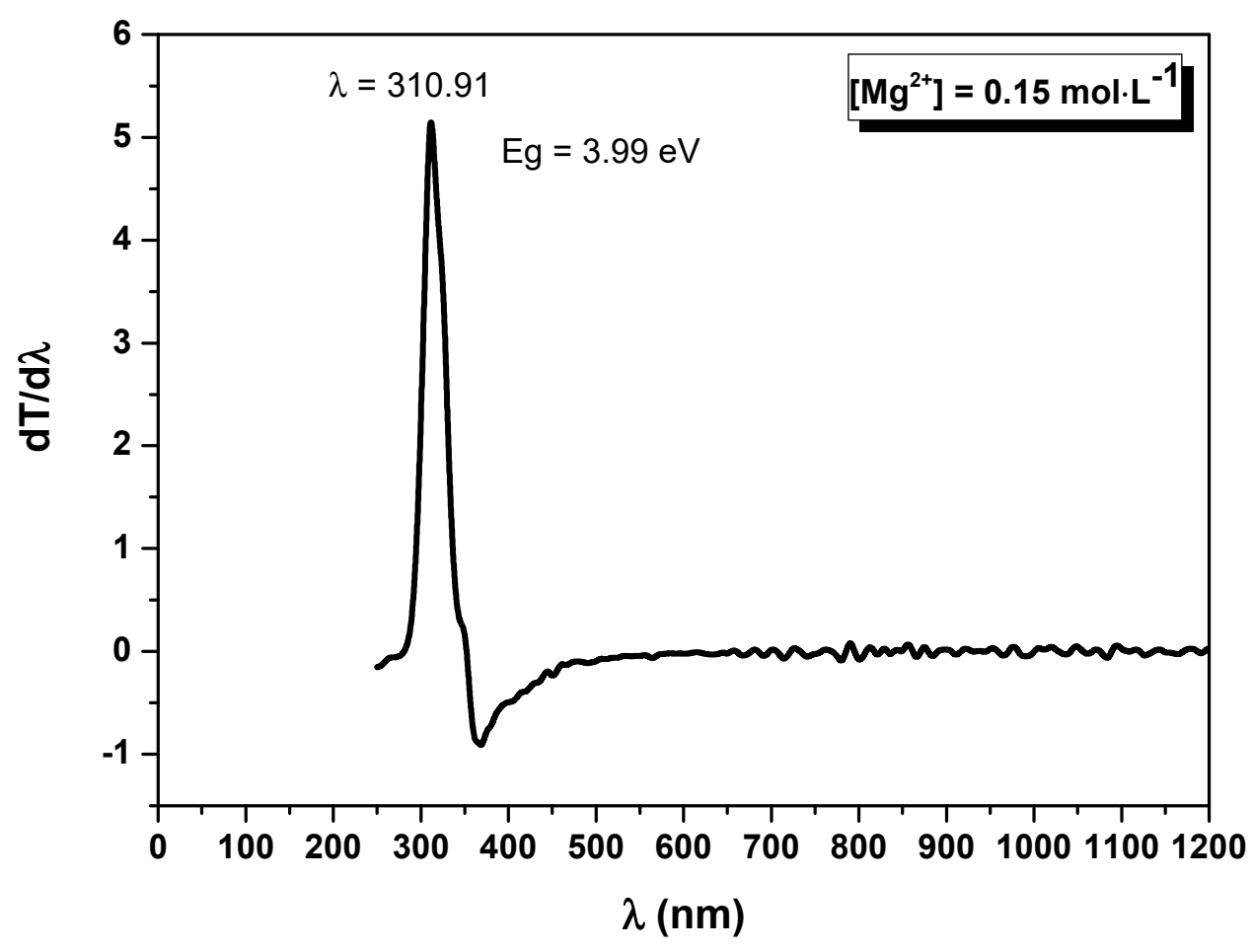

(b)

Figure 6. Band gap energy of $\mathrm{MgO}$ thin layers deposited by spray for $\left[\mathrm{Mg}^{2+}\right]=0.05 ; 0.10 ; 0.15$; and $0.20 \mathrm{~mol} \cdot \mathrm{L}^{-1}$ (a) and the value of the band gap energy of $\mathrm{MgO}$ for the $\left[\mathrm{Mg}^{2+}\right]=0.15 \mathrm{~mol} \cdot \mathrm{L}^{-1}$ concentration obtained from the graph of the derivative of T with respect to $\lambda$ as a function of $\lambda(\mathbf{b})$. 
Table 2. Band gap energies of $\mathrm{MgO}$ elaborated for different concentrations $\left[\mathrm{Mg}^{2+}\right]=0.05 ; 0.10 ; 0.15$; and $0.20 \mathrm{~mol} \cdot \mathrm{L}^{-1}$.

\begin{tabular}{ccccc}
\hline$\left[\mathbf{M g}^{\mathbf{2 +}}\right]\left(\mathbf{m o l} \cdot \mathbf{L}^{-\mathbf{1}}\right)$ & $\mathbf{0 . 0 5}$ & $\mathbf{0 . 1 0}$ & $\mathbf{0 . 1 5}$ & $\mathbf{0 . 2 0}$ \\
\hline band gap energy $(\mathrm{eV})$ & 4.08 & 4.07 & 4.00 & 4.01 \\
\hline
\end{tabular}

The refractive index $(n)$ was calculated using the following relation [31]:

$$
n=\frac{1+\left[1-\left(\frac{1-R}{1+R}\right)^{2}\left(1+\left(\frac{\lambda . \alpha}{4 \pi}\right)^{2}\right)\right]^{\frac{1}{2}}}{\frac{1-R}{1+R}}
$$

where: $\alpha$ and $R$ are the absorption coefficient and the reflection, respectively. Figure 7 illustrates the refractive index versus the wavelength $(\lambda)$ for $\mathrm{MgO}$ thin layers obtained from spray solutions with different magnesium concentrations. Figure 7 shows that $n$ varies in the range from 1.5 to 2.2. According to Tables 1 and 3, the variation in the refractive index follows the variation in the film thickness and the reduction in band gap energy, especially for $\left[\mathrm{Mg}^{2+}\right]=0.15 \mathrm{~mol} \cdot \mathrm{L}^{-1}$.

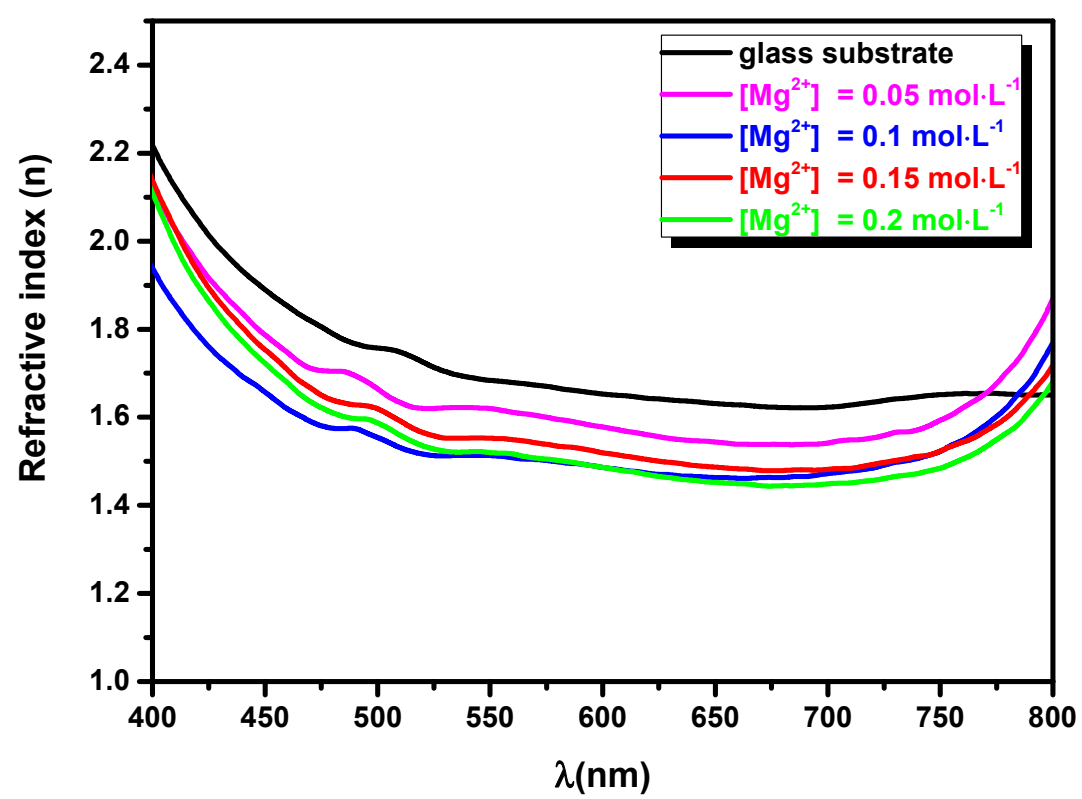

Figure 7. Variation in the refractive index (n) for $\mathrm{MgO}$ layers synthesized by spray for $\left[\mathrm{Mg}^{2+}\right]=0.05$; $0.10 ; 0.15$; and $0.20 \mathrm{~mol} \cdot \mathrm{L}^{-1}$.

Table 3. Film thickness of $\mathrm{MgO}$ synthesized with $\left[\mathrm{Mg}^{2+}\right]=0.05 ; 0.10 ; 0.15$; and $0.20 \mathrm{~mol} \cdot \mathrm{L}^{-1}$.

\begin{tabular}{ccccc}
\hline$\left[\mathbf{M g}^{2+}\right]\left(\mathbf{m o l} \cdot \mathbf{L}^{-1}\right)$ & $\mathbf{0 . 0 5}$ & $\mathbf{0 . 1}$ & $\mathbf{0 . 1 5}$ & $\mathbf{0 . 2}$ \\
\hline Thickness $(\mu \mathrm{m})$ & 0.11 & 0.22 & 0.29 & 0.40 \\
\hline
\end{tabular}

\subsection{Photoluminescence (PL)}

We performed photoluminescence measurements at 200 and $220 \mathrm{~nm}$ on the $\mathrm{MgO}$ thin layer obtained using a concentration of $0.15 \mathrm{~mol} \cdot \mathrm{L}^{-1} \mathrm{Mg}$ in the spray solution. When the film was excited with a wavelength of $220 \mathrm{~nm}$ (Supplementary Material, Figure S1), we observed the presence of emission peaks at 3.35, 3.16 and $2.32 \mathrm{eV}$, which were attributed to defect center F2, F + and F, respectively, according to Kotomin et al. [32].

Figure 8 displays the photoluminescence spectra of $\mathrm{MgO}$ thin films synthesized with $\left[\mathrm{Mg}^{2+}\right]=0.15 \mathrm{~mol} \cdot \mathrm{L}^{-1}$ excited with a wavelength of $200 \mathrm{~nm}$, where only two emission peaks were observed at $310 \mathrm{~nm}$ and $341 \mathrm{~nm}$, which correspond to 4 and $3.63 \mathrm{eV}$, respectively. These 
results agree with the value of the band gap energy of $\mathrm{MgO}$ for the $\left[\mathrm{Mg}^{2+}\right]=0.15 \mathrm{~mol} \cdot \mathrm{L}^{-1}$ concentration obtained from the graph of the derivative of $\mathrm{T}$ with respect to $\lambda$ as a function of $\lambda$ in Figure 6.

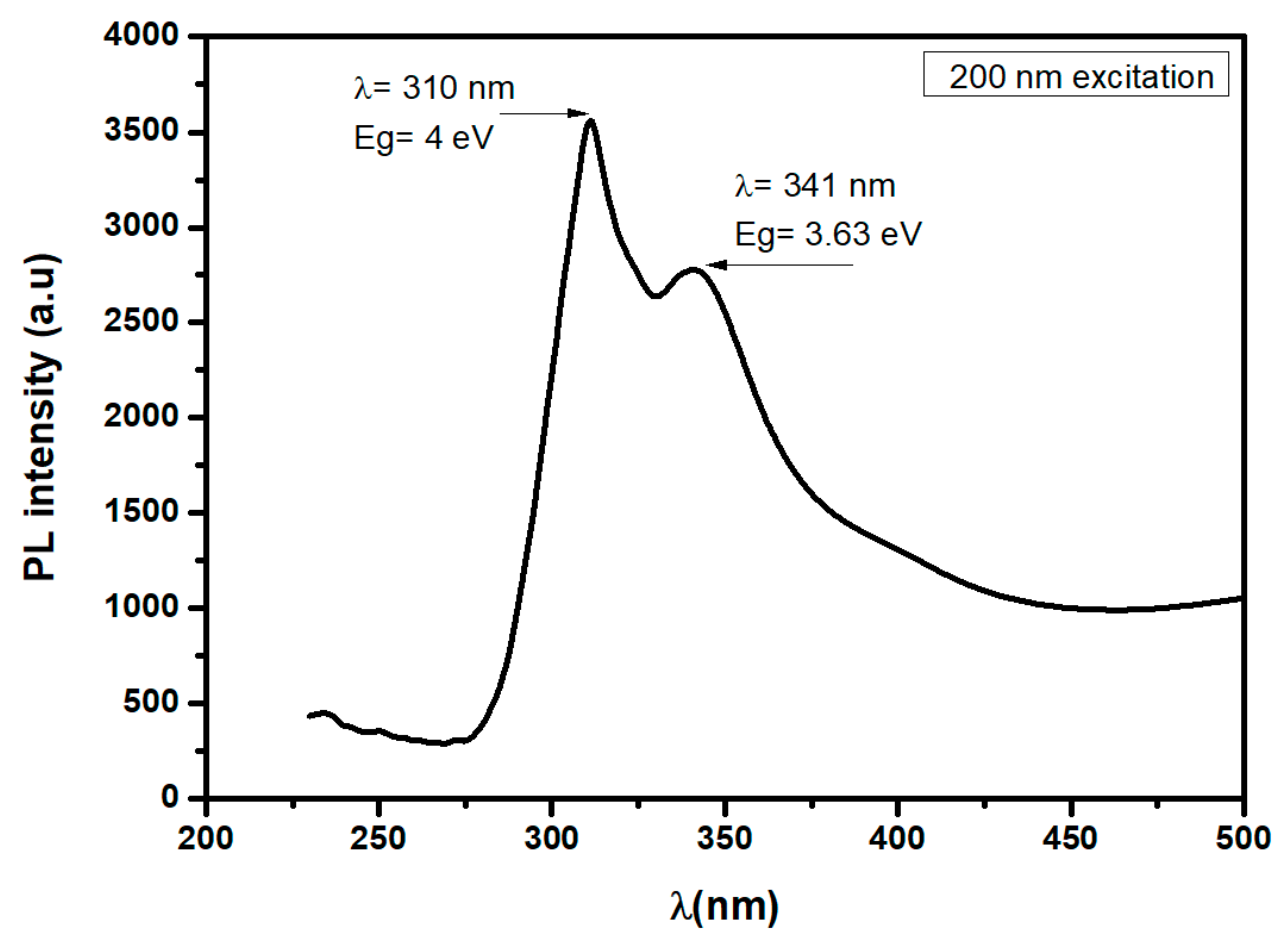

Figure 8. PL emission spectrum for $200 \mathrm{~nm}$ excitation of $\mathrm{MgO}$ thin films prepared with $\left[\mathrm{Mg}^{2+}\right]=0.15 \mathrm{~mol} \cdot \mathrm{L}^{-1}$.

\subsection{Photocatalysis Process}

Figure 9 shows the photocatalytic activity of $\mathrm{MgO}\left(\left[\mathrm{Mg}^{2+}\right]=0.15 \mathrm{~mol} \cdot \mathrm{L}^{-1}\right)$ thin film at different times (i.e., 30, 60, 90, 120, 150 and $180 \mathrm{~min}$ ) under sunlight illumination. The $\mathrm{MgO}$ thin layer effectively decomposed the aqueous methylene blue (MB) after $180 \mathrm{~min}$. In order to study the photocatalytic degradation, we calculated the photodegradation rate of $\mathrm{MgO}$ using the following expression [3]:

$$
\text { Photodegradation rate }=\frac{C_{0}-C}{C_{0}} \times 100
$$

where $C$ and $C_{0}$ are the absorbance values of the MB dye solution with and without the $\mathrm{MgO}$ sample, respectively.

The photodegradation rate of MB dye under sunlight irradiation at different times is illustrated in Figure 10. The value calculated for the photodegradation rate was about 83\% after $180 \mathrm{~min}$. This result could be related to the higher surface roughness of the $\mathrm{MgO}$ thin layer obtained with $\left[\mathrm{Mg}^{2+}\right]=0.15 \mathrm{~mol} \cdot \mathrm{L}^{-1}$.

The kinetic constant was investigated from the following expression [33]:

$$
\frac{\mathrm{dC}}{\mathrm{dt}}=-k \mathrm{C}
$$

Figure 11 displays the kinetic constant of the $\mathrm{MgO}$ thin film, which confirms the assumption of the first order of the kinetic constant. Plotting the $\operatorname{Ln}\left(\frac{C_{0}}{C}\right)$ curve as a function of time, the $k_{1}$ value of the MB solution without sample $\left(\operatorname{Ln}\left(\frac{C_{0}}{C}\right)=k_{1} \cdot t\right)$ and $k_{2}$ with the $\mathrm{MgO}$ sample $\left(\operatorname{Ln}\left(\frac{\mathcal{C}_{0}}{\mathrm{C}}\right)=\mathrm{k}_{2} . \mathrm{t}\right)$ were equal to $0.1710^{-3} \mathrm{~s}^{-1}$ and $0.1310^{-3} \mathrm{~s}^{-1}$, respectively. The kinetic constant $\left(\mathrm{k}=0.1710^{-3} \mathrm{~s}^{-1}=0.01 \mathrm{~min}^{-1}\right)$ is much smaller than $\mathrm{k}=0.30 \mathrm{~min}^{-1}$, obtained by Demirci et al. [10], who used UV light. In our experiments, we used the natural 
solar light to break down the $\mathrm{MB}$, which has an intensity lower than that of a UV lamp. We can improve the kinetic constant by doping the $\mathrm{MgO}$. In fact, doping or co-doping $\mathrm{MgO}$ with transition metals or with rare earth elements also increases the surface roughness, which increases the specific contact surface between the $\mathrm{MB}$ solution and the $\mathrm{MgO}$ material, increasing the photocatalytic efficiency, as confirmed by Kamoun et al. [34] for the $\mathrm{MoO}_{3}$ films co-doped with Fe or Co.

We note that $\mathrm{k}_{2}$ is greater than $\mathrm{k}_{1}$, confirming the efficiency of the $\mathrm{MgO}$ material to decompose the $\mathrm{MB}$ dye. This study suggests that the $\mathrm{MgO}$ thin film is a good photocatalyst for removing organic pollutants in water.

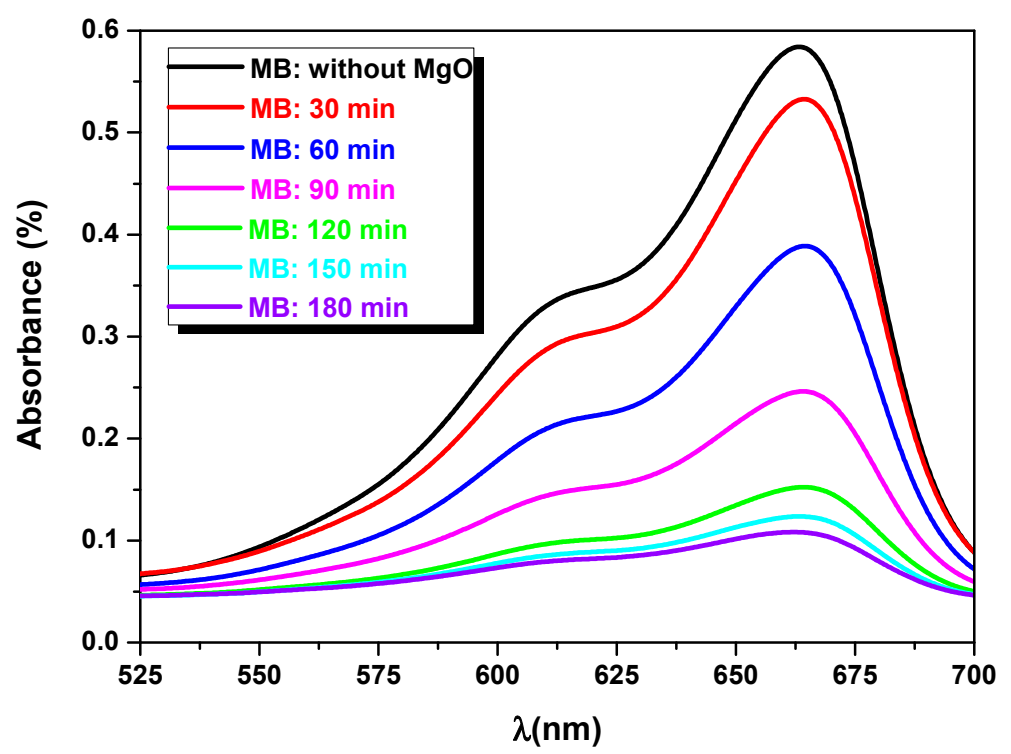

Figure 9. The temporal change in the original $\mathrm{MB}$ solution ( $0 \mathrm{~min}$ ) and with $\mathrm{MgO}$ thin films under sunlight irradiation for different times $(30,60,90,120,150$ and $180 \mathrm{~min})$.

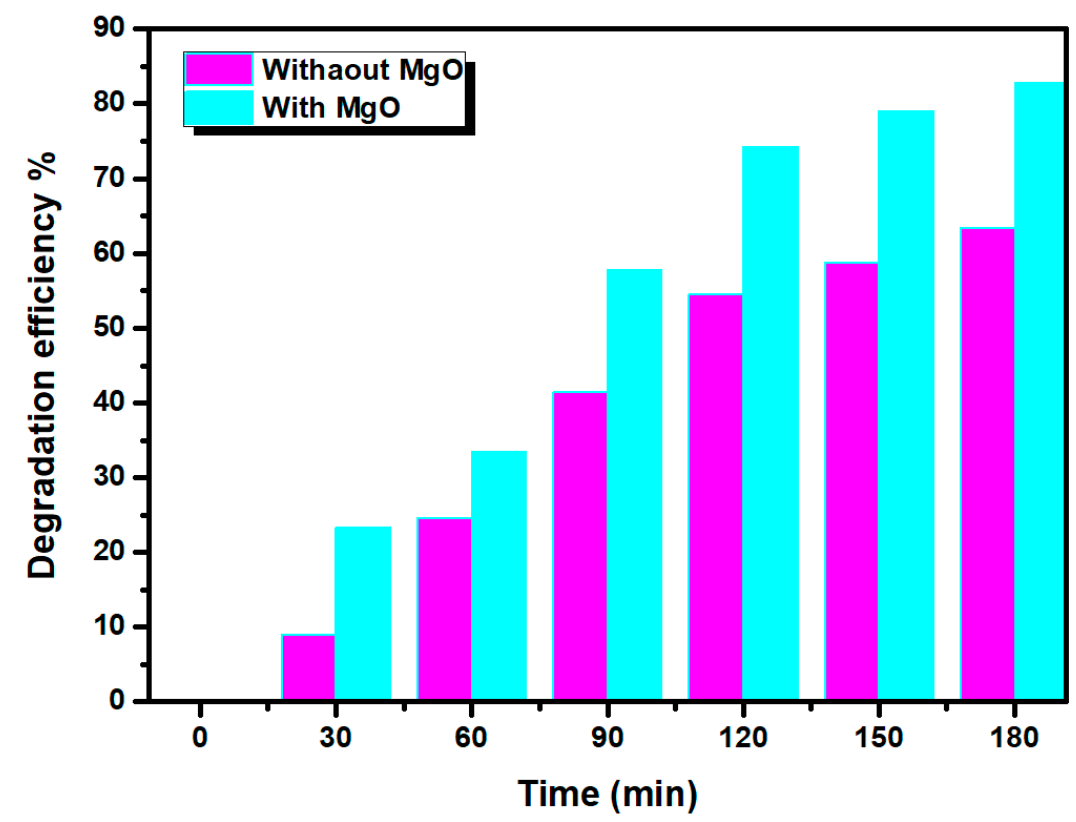

Figure 10. Photodegradation rate variation in $M B$ for two MB solutions: the one contained the optimum $\mathrm{MgO}$ (blue) and the other of original solution (pink) for different times. 


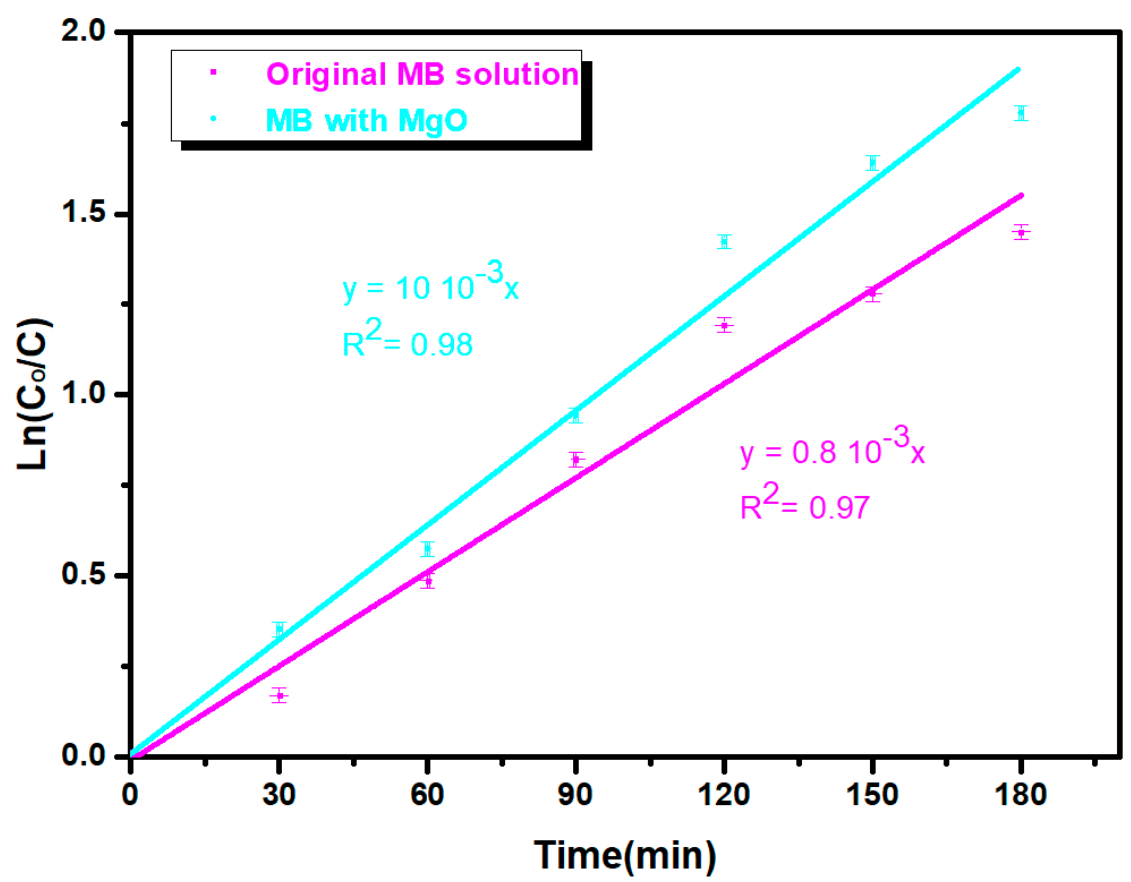

Figure 11. Variation in $\mathrm{Ln}\left(\mathrm{C}_{0} / \mathrm{C}\right)$ of original $\mathrm{MB}$ solution (pink) and with $\mathrm{MgO}$ (blue) thin films under sunlight irradiation for different times $(30,60,90,120,150$ and $180 \mathrm{~min})$. Error bar is 0.02 .

\section{Conclusions}

In summary, $\mathrm{MgO}$ thin layers were synthesized by a spray pyrolysis technique at different concentrations, i.e., $0.05 \leq\left[\mathrm{Mg}^{2+}\right] \leq 0.20 \mathrm{~mol} \cdot \mathrm{L}^{-1}$. It was found that the best results were obtained for $\left[\mathrm{Mg}^{2+}\right]=0.15 \mathrm{~mol} \cdot \mathrm{L}^{-1}$. The XRD and Maud software revealed that the good $\mathrm{MgO}$ phase crystallized into a face-centered cubic structure along (200) with preferential orientation. The energy band gap value of $\mathrm{MgO}$ was estimated by the Tauc relationship, giving an energy gap value near to $4 \mathrm{eV}$ for $\mathrm{MgO}$ obtained using $\left[\mathrm{Mg}^{2+}\right]=0.15 \mathrm{~mol} \cdot \mathrm{L}^{-1}$. Noticeable optical transmission behavior of the $\mathrm{MgO}$ thin films includes that the $\mathrm{T}(\%)$ values exceeded $85 \%$ in the visible region and were higher than $100 \%$ in the UV region. Owing to its intrinsic properties, we observed that $\mathrm{MgO}$ obtained by an inexpensive method such as spray pyrolysis has a high absorption of water molecules, which was also confirmed by FTIR analysis. Because of these characteristics, the $\mathrm{MgO}$ thin film can be used as a humidity sensor. Additionally, the $\mathrm{MgO}$ thin film presents good efficiency for the degradation of MB dye under solar irradiation, which recommends this material for photocatalysis water treatment.

Supplementary Materials: The following are available online at https:/ /www.mdpi.com/article/10 $.3390 /$ nano11113076/s1, Figure S1. PL emission spectrum for $220 \mathrm{~nm}$ excitation of $\mathrm{MgO}$ thin films prepared with $\left[\mathrm{Mg}^{2+}\right]=0.15 \mathrm{~mol} \cdot \mathrm{L}^{-1}$.

Author Contributions: Conceptualization, M.T. and N.J.; growth of $\mathrm{MgO}$ films for different magnesium concentrations, C.N.; physical analysis and discussions, C.B.; DRX measurements, B.A.; SEM investigation, L.A.; investigation and supervision, R.V.; methodology, validation and supervision, N.T.K. All authors have read and agreed to the published version of the manuscript.

Funding: This research received no external funding.

Data Availability Statement: The data presented in this study are available on request from the corresponding author. The data are not publicly available due to funder retention policies.

Acknowledgments: Our thanks for helping with characterization go to the Laboratory of Mineral Materials and their Applications, Laboratoire de Physico-chimie des Matériaux Minéraux et leurs Applications, Centre National des Recherches en Sciences des Matériaux, BP No.73, 8027 Soliman, Tunisia. 
Conflicts of Interest: The authors declare no conflict of interest.

\section{References}

1. Causà, M.; Dovesi, R.; Pisani, C.; Roetti, C. Electronic structure and stability of different crystal phases of magnesium oxide. Phys. Rev. B 1986, 33, 1308-1316. [CrossRef] [PubMed]

2. Popov, A.; Kotomin, E.; Maier, J. Basic properties of the F-type centers in halides, oxides and perovskites. Nucl. Instruments Methods Phys. Res. Sect. B Beam Interactions Mater. Atoms 2010, 268, 3084-3089. [CrossRef]

3. Tlili, M.; Jebbari, N.; Naffouti, W.; Kamoun, N.T. Effect of precursor nature on physical properties of chemically sprayed MgO thin films for optoelectronic application. Eur. Phys. J. Plus 2020, 135, 1-12. [CrossRef]

4. Roessler, D.M.; Walker, W.C. Electronic Spectrum and Ultraviolet Optical Properties of Crystalline MgO. Phys. Rev. 1967, 159, 733-738. [CrossRef]

5. Heo, S.; Cho, E.; Lee, H.-I.; Park, G.S.; Kang, H.J.; Nagatomi, T.; Choi, P.; Choi, B.-D. Band gap and defect states of MgO thin films investigated using reflection electron energy loss spectroscopy. AIP Adv. 2015, 5, 077167. [CrossRef]

6. Cai, L.; Chen, J.; Liu, Z.; Wang, H.; Yang, H.; Ding, W. Magnesium Oxide Nanoparticles: Effective Agricultural Antibacterial Agent Against Ralstonia solanacearum. Front. Microbiol. 2018, 9, 790. [CrossRef] [PubMed]

7. Téllez, D.A.L.; Yadava, Y.P.; Ferreira, J.M.; Aguiar, J.A. Chemical and physical stability of MgO with superconductors. Supercond. Sci. Technol. 1999, 12, 18-23. [CrossRef]

8. Tang, Z.-X.; Lv, B.-F. MgO nanoparticles as antibacterial agent: Preparation and activity. Braz. J. Chem. Eng. 2014, 31, 591-601. [CrossRef]

9. Nguyen, N.-Y.T.; Grelling, N.; Wetteland, C.L.; Rosario, R.; Liu, H.N. Antimicrobial Activities and Mechanisms of Magnesium Oxide Nanoparticles (nMgO) against Pathogenic Bacteria, Yeasts, and Biofilms. Sci. Rep. 2018, 8, 16260. [CrossRef]

10. Demirci, S.; Öztürk, B.; Yildirim, S.; Bakal, F.; Erol, M.; Sancakoğlu, O.; Yigit, R.; Celik, E.; Batar, T. Synthesis and comparison of the photocatalytic activities of flame spray pyrolysis and sol-gel derived magnesium oxide nano-scale particles. Mater. Sci. Semicond. Process. 2015, 34, 154-161. [CrossRef]

11. Dagar, J.; Castro-Hermosa, S.; Lucarelli, G.; Cacialli, F.; Brown, T.M. Highly efficient perovskite solar cells for light harvesting under indoor illumination via solution processed SnO2/MgO composite electron transport layers. Nano Energy 2018, 49, 290-299. [CrossRef]

12. Ma, J.; Yang, G.; Qin, M.; Zheng, X.; Lei, H.; Chen, C.; Chen, Z.; Guo, Y.; Han, H.; Zhao, X.; et al. MgO Nanoparticle Modified Anode for Highly Efficient SnO2 -Based Planar Perovskite Solar Cells. Adv. Sci. 2017, 4, 1700031. [CrossRef]

13. Poonguzhali, R.V.; Kumar, E.R.; Pushpagiri, T.; Steephen, A.; Arunadevi, N.; Baskoutas, S. Lemon juice (natural fuel) assisted synthesis of MgO nanorods for LPG gas sensor applications. Solid State Commun. 2021, 325, 114161. [CrossRef]

14. Ho, I.-C.; Xu, Y.; Mackenzie, J.D. Electrical and optical properties of mgo thin film prepared by sol-gel technique. J. Sol-Gel Sci. Technol. 1997, 9, 295-301. [CrossRef]

15. Wahab, R.; Ansari, S.; Dar, M.; Kim, Y.S.; Shin, H.S. Synthesis of Magnesium Oxide Nanoparticles by Sol-Gel Process. Mater. Sci. Forum 2007, 2007, 983-986. [CrossRef]

16. Zulkefle, H.; Ismail, L.N.; Bakar, R.A.; Mahmood, M.R. Molar concentration effect on mgo thin films properties. In Proceedings of the 2011 IEEE Symposium on Industrial Electronics and Applications, Langkawi, Malaysia, 25-28 September 2011; Volume 2011, pp. $468-471$.

17. Carta, G.; El Habra, N.; Crociani, L.; Rossetto, G.; Zanella, P.; Paolucci, G.; Barreca, D.; Tondello, E. CVD of MgO Thin Films from Bis(methylcyclopentadienyl) Magnesium. Chem. Vap. Depos. 2007, 13, 185-189. [CrossRef]

18. Kaneko, S.; Ito, T.; Soga, M.; Motoizumi, Y.; Yasui, M.; Hirabayashi, Y.; Ozawa, T.; Yoshimoto, M. Growth of Nanocubic MgO on Silicon Substrate by Pulsed Laser Deposition. Jpn. J. Appl. Phys. 2013, 52, 01AN02. [CrossRef]

19. Choi, Y.W.; Kim, J. Reactive sputtering of magnesium oxide thin film for plasma display panel applications. Thin Solid Films 2004, 460, 295-299. [CrossRef]

20. Płóciennik, P.; Guichaoua, D.; Zawadzka, A.; Korcala, A.; Strzelecki, J.; Trzaska, P.; Sahraoui, B. Optical properties of MgO thin films grown by laser ablation technique. Opt. Quantum Electron. 2016, 48, 277. [CrossRef]

21. Niu, F.; Hoerman, B.H.; Wessels, B.W. Metalorganic molecular beam epitaxy of magnesium oxide on silicon. MRS Online Proc. Libr. 2000, 619, 149-154. [CrossRef]

22. Raj, A.M.E.; Nehru, L.C.; Jayachandran, M.; Sanjeeviraja, C. Spray pyrolysis deposition and characterization of highly (100) oriented magnesium oxide thin films. Cryst. Res. Technol. 2007, 42, 867-875. [CrossRef]

23. Serga, V.; Kulikova, L.; Cvetkov, A.; Chikvaidze, G.; Kodols, M. Extractive-Pyrolytic Method for Au/MeOx Nanocomposites Production. Key Eng. Mater. 2014, 604, 118-121. [CrossRef]

24. Ashok, C.; Rao, K.V.; Chakra, C.S.; Rao, K.G. Mgo nanoparticles prepared by microwave-irradiation technique and its seed germination application. Nano Trends A J. Nanotechnol. Appl. 2016, 18, 10-17.

25. Kandiban, M.; Vigneshwaran, P.; Potheher, I.V. Synthesis and characterization of mgo nanoparticles for photocatalytic applications. In Proceedings of the National Conference on Advances in Crystal Growwth and Nanotechnology, Kottayam, India, 15-16 January 2015. 
26. Devaraja, P.; Avadhani, D.; Prashantha, S.; Nagabhushana, H.; Sharma, S.; Nagabhushana, B.; Nagaswarupa, H. Synthesis, structural and luminescence studies of magnesium oxide nanopowder. Spectrochim. Acta Part A Mol. Biomol. Spectrosc. 2014, 118, 847-851. [CrossRef]

27. Mageshwari, K.; Mali, S.S.; Sathyamoorthy, R.; Patil, P.S. Template-free synthesis of MgO nanoparticles for effective photocatalytic applications. Powder Technol. 2013, 249, 456-462. [CrossRef]

28. Savchyn, P.; Karbovnyk, I.; Vistovskyy, V.; Voloshinovskii, A.; Pankratov, V.; Cestelli Guidi, M.; Mirri, C.; Myahkota, O.; Riabtseva, A.; Mitina, N.; et al. Vibrational properties of lapo4 nanoparticles in mid- and far-infrared domain. J. Appl. Phys. 2012, 112, 124309. [CrossRef]

29. Barhoumi, A.; Leroy, G.; Duponchel, B.; Gest, J.; Yang, L.; Waldhoff, N.; Guermazi, S. Aluminum doped ZnO thin films deposited by direct current sputtering: Structural and optical properties. Superlattices Microstruct. 2015, 82, 483-498. [CrossRef]

30. Nefzi, C.; Souli, M.; Beji, N.; Mejri, A.; Kamoun-Turki, N. Improvement of structural, optical and electrical properties of iron doped indium oxide thin films by high gamma radiations for photocatalysis applications. Mater. Sci. Semicond. Process. 2019, 90, 32-40. [CrossRef]

31. Ayed, R.B.; Ajili, M.; Thamri, A.; Kamoun, N.T.; Abdelghani, A. Substrate temperature effect on the crystal growth and optoelectronic properties of sprayed $\alpha-\mathrm{Fe}_{2} \mathrm{O}_{3}$ thin films: Application to gas sensor and novel photovoltaic solar cell structure. Mater. Technol. 2018, 33, 769-783. [CrossRef]

32. Kotomin, E.; Popov, A.I. Radiation-induced point defects in simple oxides. Nucl. Instrum. Methods Phys. Res. Sect. B Beam Interact. Mater. Atoms 1998, 141, 1-15. [CrossRef]

33. Ammari, Y.; Elatmani, K.; Qourzal, S.; Bakas, I.; Ejakouk, E.; Ait-Ichou, Y. Etude cinétique de la dégradation photocatalytique du colorant bleu de méthylène en présence de dioxyde de titane $\left(\mathrm{TiO}_{2}\right)$, en suspension aqueuse (kinetic study of the photocatalytic degradation of methylene blue dye in the presence of titanium dioxide $\left(\mathrm{TiO}_{2}\right)$, in aqueous suspension). J. Mater. Environ. Sci. 2016, 7, 8 .

34. Kamoun, O.; Mami, A.; Amara, M.A.; Vidu, R.; Amlouk, M. Nanostructured Fe,Co-Codoped MoO 3 Thin Films. Micromachines 2019, 10, 138. [CrossRef] [PubMed] 